\title{
Analysis of Quality Control of Production of Bottled Water
}

\author{
Agustina Hotma Uli Tumanggor ${ }^{1}$, Kurniawan ${ }^{2}$, Rianti Indah Lestari ${ }^{3}$ \\ \{agustina.hotma@gmail.com ${ }^{1}$, Kurniawanh1f112208@gmail.com ${ }^{2}$, riantyindah29@gmail.com ${ }^{3}$ \} \\ ${ }^{1}$ Industrial Engineeering Department Sari Mulia University Banjarmasin, Jl. Pramuka No. 2 Pemurus \\ Luar Banjarmasin Kalimantan Selatan \\ ${ }^{2}$ Mechanical Engineering Lambung Mangkurat University Banjarbaru, Jl. Achad Yani Km. 36 \\ Banjarbaru Kalimantan Selatan \\ ${ }^{3}$ Industrial Engineeering Department Sari Mulia University Banjarmasin, Jl. Pramuka No. 2 Pemurus \\ Luar Banjarmasin Kalimantan Selatan
}

\begin{abstract}
Bottled water producers are experiencing quality problems in glass packaging production lines. Six Sigma is a methodology that provides tools for improving business processes to reduce process variation and improve product quality using the DMAIC approach. The results of measurement data obtained by key Critical to Quality (CTQ) based on Pareto Diagram, 36.7\% of the highest disability was in the type of lid defect. 5.08 sigma level which is not yet reached the level of six sigma because of the high defect products. From the causal diagram analysis, the causes of disability are derived from the machine, material and human factors. FMEA results are known that the seal disc is dirty when the production process is running. The improvement is to check the condition of the sealing unit before carrying out the production process and sand the sealing unit once a week on an uneven surface.
\end{abstract}

Keywords: AMDK, Six Sigma, Define, Measure, Analyze, Improve and Control (DMAIC), Failure Mode and Effect Analysis (FMEA), Critical to Quality (CTQ)

\section{Introduction}

PT Varia Inti Tirta is one of the individual companies engaged in the bottled water industry (AMDK). The company's production is the VIT brand product. VIT is a bottled mineral water product that is still one parent with AQUA, produced from selected springs that meet its cleanliness standard, processed with the best technology that makes VIT safe, healthy and fresh for consumption. From preliminary observations of the existing data in the company, especially in the production of $220 \mathrm{ml}$ VIT cup mineral water many defective products were found. Among them is the leak lid on the cup, the volume of water filling is less, the lid is tilted, reject filler ISI (RFI), lid defects, reject filler packaging (RFK), dirty water and packing fall.

Based on the description of the problem in the VIT production process with $220 \mathrm{ml}$ packaging and found defects in the product process, the effort to solve the problem is by applying the DMAIC Method (Define, Measure, Analyze, Improve and Control)[1]. This concept has a clear system in improving the expected process, starting from identifying problems, making measurements, analyzing the root of the problem and providing suggestions 
for improvement and a clear control plan for quality.

\section{Research Methodology}

This research was conducted in the following stages:

a. Conducting preliminary observations, this is done in determining the formulation of the problem, looking for initial data and the actual condition of the research object

b. Conducting literature study

c. Determine research objectives

d. Collecting data, including product defect data, production data, machine data as well as several interviews (regarding procedures and policies) and questionnaires (regarding the level of severity, occurance, detection)

e. Perform data processing and analysis, several stages of DMAIC (Define, Measure, Analyze, Improve, Control) to achieve research objectives

f. Take conclusions and suggestions

\section{Data Processing and Analysis}

At this stage the DMAIC Method (Define, Measure, Analyze, Improve, Control) is carried out as follows:

\subsection{Define Stage}

The define stage is the initial stage of Six Sigma [2]. This stage aims to find the process that has the biggest contribution in causing disability or poor quality of the final VIT product in $220 \mathrm{ml}$ packaging. The define stage consists of the following steps:

1) Mapping the Production Process

Mapping aims to determine and identify the VIT production process in $220 \mathrm{ml}$ packaging in general. There are 12 processes in the VIT production process with 220 $\mathrm{ml}$ packaging, starting from a water source from a wellbore that has a depth of 180 meters then sand filter, manganese greensand, carbon filter, cartridge, final tank, filler, $220 \mathrm{ml}$ cup, VC visualization, packing then head to the product warehouse and finishing in the goods loading section for the finished product.

2) Identification of Quality Characteristics of VIT with $220 \mathrm{ml}$ packaging

At this stage what will be done is to determine the Technical to Quality (CTQ) to find out what are the characteristics of the quality of VIT with $220 \mathrm{ml}$ packaging. Based on the results of information from the quality reports obtained from the production and quality control sections the quality and disability characteristics that occur in VIT products with $220 \mathrm{ml}$ packaging in terms of visual quality, namely:

a) Leaking Lid 
Leaking Lids in the form of mounting the lid on the cup that has been filled with water that is not right or not right so that it causes a leak on the top of the cup.

b) Less Volume

The standard volume of filling a VIT product in $220 \mathrm{ml}$ packaging. Volume defects in the form of less volume. The product is said to have less volume when filling a $220 \mathrm{ml}$ product volume with the lower limit not to exceed the line on the cup.

c) Tilted lid

Angled lid is an uneven lid on the part of the glass that has been filled with water.

d) ISI Reject Filler (RFI)

ISI Reject Filler is a type of defect in the form of saggy lid on the cup so that the lid expands or is convex upward.

e) Lid Defects

Lid defects in the form of defects that exist on the lid in the form of objects attached to the lid so that it covers the existing brand on the ait drink packaging.

f) Packaging Reject Filler (RFK)

Reject Filler Packaging is a type of defect in the form of dented cup and lid attached to the package.

g) Dirty Water

In the finished product in it, there is dirt due to the powder from the cup and the powder from the lid.

h) Fall Packing

Falling Packing is a type of disability in the form of breakage, leakage and defects because when packing falls to the floor resulting in rupture.

3) Selection of Key CTQ

Key Critical to Quality (CTQ) characteristics are the most influential CTQ on the quality of VIT with $220 \mathrm{ml}$ packaging. To determine the key quality characteristics (CTQ) is to sort the AQUA product defect data with $220 \mathrm{ml}$ packaging in the filling and packaging process, from January to December 2015. Next, with the Pareto diagram to find out the highest frequency of disability which will be used as key quality characteristics (CTQ). 


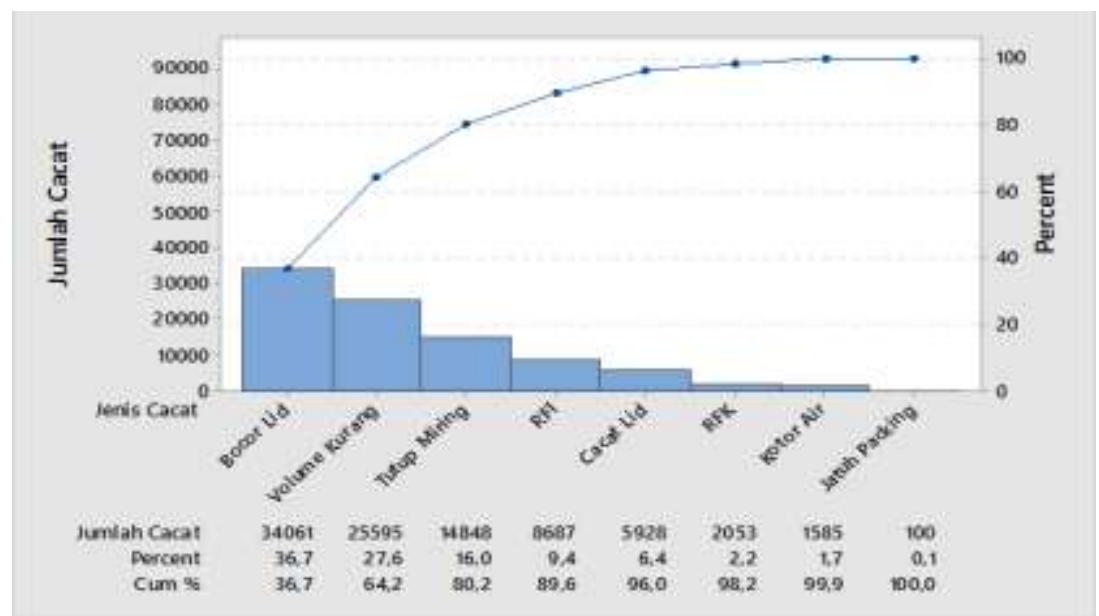

Fig. 2. Pareto diagram based on the VIT Recordability in 2015

Based on the Pareto diagram in Fig 2. It is known that 3 types of the biggest defects that will be examined. $36.7 \%$ of the total defects that occurred were the leak lid which had the largest presentation value, the volume was less by $27.6 \%$ and the lid was tilted by $16.0 \%$. Then the key Critical to Quality (CTQ) in this study is leaky lid, less volume and lopsided lid.

\subsection{Measure Stage}

The Measure Phase can also be interpreted as a stage of measuring the sigma level. Sigma measurement is done to determine the quality of the company's products [3]. Because by knowing the level of sigma level can be used as one of the parameters of the success of achieving quality targets. Where the higher level of sigma will make the level of disability produced per million opportunities (DPMO) lower.

At this stage the sigma level will be measured in the filling process in producing $220 \mathrm{ml}$ VIT products. What needs to be done is to collect data on product defects in the filling process from January to December 2015 as in the following table.

Table 1. Data Disability Level of Drinking Water Products in Cups of $220 \mathrm{ml}$

\begin{tabular}{ccccccccccc}
\hline Month & $\begin{array}{c}\text { Leaked } \\
\text { LID }\end{array}$ & $\begin{array}{c}\text { LID } \\
\text { defects }\end{array}$ & Tilted lid & $\begin{array}{c}\text { Less } \\
\text { Volume }\end{array}$ & RFI & RFK & $\begin{array}{c}\text { Dirty } \\
\text { Water }\end{array}$ & $\begin{array}{c}\text { Fall } \\
\text { packing }\end{array}$ & $\begin{array}{c}\text { Number } \\
\text { of defects }\end{array}$ & $\begin{array}{c}\text { Production } \\
\text { Amount }\end{array}$ \\
\hline 1 & 5434 & 709 & 3008 & 1828 & 932 & 323 & 72 & 27 & 12333 & 5504832 \\
2 & 1425 & 221 & 464 & 1188 & 196 & 115 & 39 & 1 & 3649 & 2990592 \\
3 & 1110 & 295 & 1700 & 5995 & 138 & 69 & 36 & 2 & 9345 & 3170112 \\
4 & 1237 & 421 & 1760 & 2092 & 428 & 134 & 56 & 3 & 6131 & 5263776 \\
5 & 1540 & 445 & 1354 & 1831 & 1132 & 245 & 28 & 1 & 6576 & 6545712 \\
6 & 1542 & 529 & 1167 & 2198 & 620 & 91 & 83 & - & 6230 & 6521088
\end{tabular}




\begin{tabular}{ccccccccccc}
7 & 2129 & 540 & 1793 & 895 & 498 & 108 & 129 & - & 6092 & 5269440 \\
8 & 4029 & 912 & 858 & 1707 & 1320 & 340 & 270 & 58 & 9494 & 6789504 \\
9 & 4316 & 644 & 643 & 1743 & 607 & 147 & 211 & 1 & 8312 & 6792000 \\
10 & 4285 & 274 & 927 & 923 & 772 & 162 & 203 & - & 7546 & 6169824 \\
11 & 4202 & 588 & 417 & 2065 & 1243 & 185 & 247 & - & 8947 & 5635488 \\
12 & 2812 & 350 & 757 & 3130 & 801 & 134 & 211 & 7 & 8202 & 5756976 \\
\hline Total & $\mathbf{3 4 0 6 1}$ & $\mathbf{5 9 2 8}$ & $\mathbf{1 4 8 4 8}$ & $\mathbf{2 5 5 9 5}$ & $\mathbf{8 6 8 7}$ & $\mathbf{2 0 5 3}$ & $\mathbf{1 5 8 5}$ & $\mathbf{1 0 0}$ & $\mathbf{9 2 8 5 7}$ & $\mathbf{6 6 4 0 9 3 4 4}$ \\
\hline
\end{tabular}

Furthermore, from Table 1 is calculated and converted to sigma level values for January to December 2015 as follows:

Table 2. Sigma Level Measurement Results

\begin{tabular}{cccccccc} 
Observation & $\begin{array}{c}\text { Number } \\
\text { of Defects }\end{array}$ & $\begin{array}{c}\text { Production } \\
\text { Amount }\end{array}$ & OP & TOP & DPO & DPMO & Sigma \\
\hline Januari & 12333 & 5504832 & 8 & 44038656 & 0,000280049 & 280,049 & 4,95 \\
February & 3649 & 2990592 & 8 & 23924736 & 0,00015252 & 152,520 & 5,11 \\
March & 9345 & 3170112 & 8 & 25360896 & 0,000368481 & 368,481 & 4,88 \\
April & 6131 & 5263776 & 8 & 42110208 & 0,000145594 & 145,594 & 5,12 \\
May & 6576 & 6545712 & 8 & 52365696 & 0,000125578 & 125,578 & 5,16 \\
June & 6230 & 6521088 & 8 & 52168704 & 0,00011942 & 119,420 & 5,17 \\
July & 6092 & 5269440 & 8 & 42155520 & 0,000144513 & 144,513 & 5,12 \\
August & 9494 & 6789504 & 8 & 54316032 & 0,000174792 & 174,792 & 5,08 \\
September & 8312 & 6792000 & 8 & 54336000 & 0,000152974 & 152,974 & 5,11 \\
October & 7546 & 6169824 & 8 & 49358592 & 0,000152881 & 152,881 & 5,11 \\
November & 8947 & 5635488 & 8 & 45083904 & 0,000198452 & 198,452 & 5,04 \\
December & 8202 & 5756976 & 8 & 46055808 & 0,000178088 & 178,088 & 5,07 \\
\hline Total & $\mathbf{9 2 8 5 7}$ & $\mathbf{6 6 4 0 9 3 4 4}$ & $\mathbf{8}$ & $\mathbf{5 3 1 2 7 4 7 5 2}$ & $\mathbf{0 , 0 0 0 1 7 4 7 8 2}$ & $\mathbf{1 7 4 , 7 8 2}$ & $\mathbf{5 , 0 8}$ \\
\hline
\end{tabular}

\subsection{Analize Stage}

The type of problem to be analyzed to determine the cause is taken in accordance with the results of the selected CTQ namely defective lid leakage, lack of volume and tilted lid defects [4]. the high defect rate will ultimately lead to the low quality of overall production.

a. Analysis of the Cause of the Problem Search by using the Cause Effect

Diagram of Cause and Effect is compiled and shaped through observation and interviews.

The greatest number of defects occurred in lid leak defect products, namely the number of defects was 34,061 cups (36.7\%). Factors for the emergence of defects will be analyzed from 
factors: human, machine, material, method, management and information. The causes of lid leak defects can be seen in Figure 3 below.

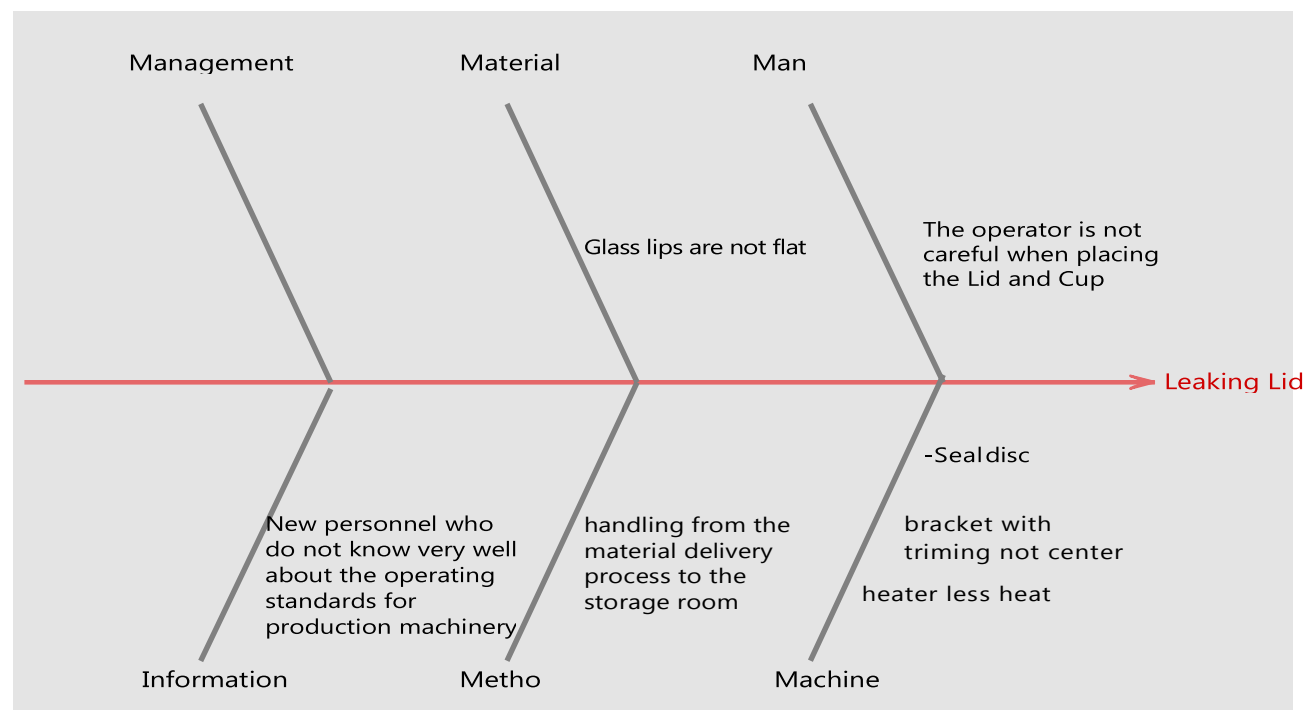

Fig 3. The Leakage Lid Fishbone Diagram

Based on the Fishbone Diagram above, it is known that the causes of the incompatibility of VIT cup $220 \mathrm{ml}$ bottled drinking water products for the VIT brand are as follows:

1) Human (man) consists of a lack of accuracy in working due to negligence in placing the lid and cup during the production process.

2) The machine includes a dirty disc seal, backet with no center trimming with less heat heater.

3) Raw material (material), cup lip is not flat because the quality of raw material from the supplier is not good.

4) Method (method), handling from the process of sending materials to the storage room.

b. Creating Failure Mode and Effect Analysis (FMEA)

Based on the Cause and Effect Diagram in the cause effect diagram above, it can be seen the causes of product defects. The next step is to design a questionnaire that aims to determine the Severity, Occurrence and Detection of the factors causing the failure that will be used in the analysis phase of the potential failure effects of variation sources using the FMEA tool.

Table 3 shows an example of FMEA, to get a Risk Priority Number (RPN) is to determine the value / scale of severity, occurrence and detection (obtained from the results of the questionnaire), the RPN calculation is used to identify priority potential failure modes. To calculate the RPN by multiplying severity, occurrence and detection. If the value of each severity, occurrence and detection is more than one, then the largest value / scale is used to calculate the RPN. 


\subsection{Improve Stage}

After the sources and root causes of the defect problem are identified, the next step is to establish a repair plan to prevent the causes of the defect from recurring so as to reduce the number of defects. At this stage also using FMEA can make proposed corrective plans (recommended action) [5].

Each failure mode has one RPN value. RPN value is the result of multiplication between severity, occurrence and detection scale. Then the RPN is arranged from the largest to the smallest so that it can be known which mode of failure is a priority for corrective action. [7. Proposed improvement plan (recommended action) that is made based on the causes of failure and failure mode data that has been made previously through FMEA. Implementation of this phase is only in the form of a proposed improvement, shown in Table 4 below.

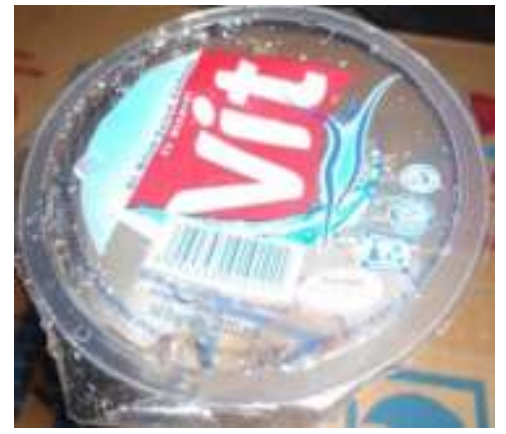

Fig 5. Types of Defects Leaking Lids

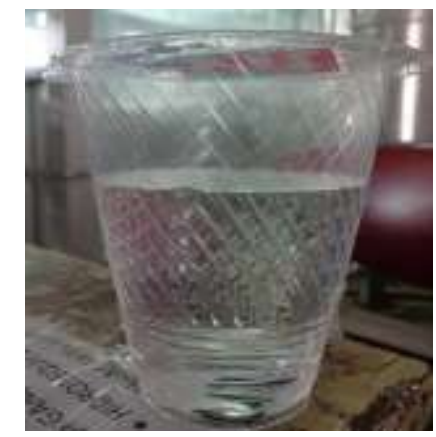

Fig 6. Type of Defect Volume Less

\section{Conclusion}

Based on research that has been done at PT. Varia Inti Tirta on $220 \mathrm{ml}$ VIT product packaging, the following conclusions can be drawn:

1. Define Stage: It is known that there are the 3 biggest types of defects to be examined. $36.7 \%$ leaked the largest lid, volume was less by $27.6 \%$ and the lid was tilted by $16.0 \%$.

2. Measure and Analysis Stage: known sigma level from January to December 2015 production has a sigma level of 5.08 with 174.782 damage in one million occasions in the production process of $220 \mathrm{ml}$ VIT Cup Drinking Water, which then calculates using the control chart $\mathrm{p}$ that results from it can be said that no data is out of control. After the Full Control Map $\mathrm{p}$ is continued using a cause-and-effect diagram in observations that often fail in the production process of the dominant engine and FMEA of each defect along with the highest RPN value, the machine with a large dirty disc seal RPN 60 .

3. Improve Stage: proposed improvement (improve) for the highest RPN, namely leaky lid, less volume and lopsided lid.

4. Control Stage: carry out checks before the production process, conduct appropriate guidance and conduct strict and disciplined supervision. 
Table 3. FMEA with RPN Value

\begin{tabular}{|c|c|c|c|c|c|c|c|c|c|c|}
\hline \multirow{3}{*}{$\begin{array}{l}\text { No } \\
1 \\
1\end{array}$} & \multirow{3}{*}{$\begin{array}{l}\text { Type of Defect } \\
\text { Leaking Lid }\end{array}$} & \multirow{5}{*}{$\begin{array}{l}\text { Component } \\
\text { Machine }\end{array}$} & \multicolumn{2}{|c|}{ Potential Failure Effects } & \multirow{2}{*}{$\mathbf{S}$} & \multirow{2}{*}{ Causes of Failure } & \multirow{2}{*}{$\mathbf{O}$} & \multirow{2}{*}{ Process Control } & \multirow{2}{*}{ D } & \multirow{2}{*}{ RPN } \\
\hline & & & Next process & Product Performance & & & & & & \\
\hline & & & Heater is not hot enough & $\begin{array}{c}\text { Lid Cup Pressing } \\
\text { Process is not perfect }\end{array}$ & 4 & $\begin{array}{c}\text { Electricity often goes out } \\
\text { of voltage less }\end{array}$ & 4 & $\begin{array}{l}\text { Check temperature on } \\
\text { a standard heater } 180 \text { - } \\
200^{\circ} \mathrm{C}\end{array}$ & 2 & 32 \\
\hline & & & $\begin{array}{c}\text { Backet with } \\
\text { Trimming is not Center }\end{array}$ & $\begin{array}{l}\text { Lid blades } \\
\text { regarding the product }\end{array}$ & 4 & $\begin{array}{l}\text { Fastening bolts loose } \\
\text { bucket }\end{array}$ & 4 & $\begin{array}{c}\text { Tightening and reset } \\
\text { on the bucket }\end{array}$ & 3 & 48 \\
\hline & & & Dirty disc seal & $\begin{array}{r}\text { The lid is torn The } \\
\text { presssing process } \\
\text { not optimal }\end{array}$ & 6 & $\begin{array}{l}\text { Lid powder stuck to Seal } \\
\text { disc }\end{array}$ & 5 & $\begin{array}{l}\text { Seal cleaning and } \\
\text { sanding dirty disc }\end{array}$ & 2 & 60 \\
\hline & & Material & Lip Cup uneven & $\begin{array}{l}\text { Pressing process } \\
\text { not perfect }\end{array}$ & 6 & $\begin{array}{l}\text { Quality of raw materials } \\
\text { from the supplier is not } \\
\text { good }\end{array}$ & 4 & $\begin{array}{l}\text { Cup uneven lips } \\
\text { separated from } \\
\text { dispenser }\end{array}$ & 2 & 48 \\
\hline & & Operator & $\begin{array}{c}\text { The operator is not careful } \\
\text { when placing the lid } \\
\text { and cup }\end{array}$ & $\begin{array}{l}\text { Products rub against } \\
\text { conveyors }\end{array}$ & 4 & $\begin{array}{l}\text { Products piled on } \\
\text { conveyor end }\end{array}$ & 3 & $\begin{array}{l}\text { The operator is notified } \\
\text { by the way be rebuked }\end{array}$ & 2 & 24 \\
\hline \multirow[t]{2}{*}{2} & \multirow[t]{2}{*}{$\begin{array}{l}\text { Volume } \\
\text { less }\end{array}$} & Machine & $\begin{array}{c}\text { Pump supply is less } \\
\text { supportive }\end{array}$ & $\begin{array}{c}\text { Product water filling is } \\
\text { not optimal }\end{array}$ & 5 & Cartridge dead end & 3 & Filter cleaning & 3 & 30 \\
\hline & & Operator & $\begin{array}{c}\text { The operator is less } \\
\text { thorough, forgetting to } \\
\text { turn on or open valve / } \\
\text { water faucet }\end{array}$ & $\begin{array}{l}\text { Water filling is not } \\
\text { perfect }\end{array}$ & 4 & $\begin{array}{l}\text { The volume of water } \\
\text { becomes less than } \\
\text { reached } 220 \mathrm{ml}\end{array}$ & 3 & $\begin{array}{c}\text { Operators are notified } \\
\text { by reprimand }\end{array}$ & 2 & 24 \\
\hline
\end{tabular}


Tabel 4. Proposed FMEA Improvements

\begin{tabular}{|c|c|c|c|c|c|c|}
\hline Priority & $\begin{array}{l}\text { Type of } \\
\text { defect }\end{array}$ & Component & $\begin{array}{l}\text { Potential } \\
\text { Failure } \\
\text { Effects }\end{array}$ & Causes of Failure & RPN & Proposed Improvement \\
\hline 1 & Leaking Lid & Machine & Dirty disc seal & $\begin{array}{c}\text { The lid powder is stuck on } \\
\text { seal disc }\end{array}$ & 60 & $\begin{array}{l}\text { - Check the condition of the sealing unit before } \\
\text { carrying out the production process } \\
\text { - Do it once a week } \\
\text { - Sanding on the surface sealing disc is uneven }\end{array}$ \\
\hline 2 & Leaking Lid & Machine & $\begin{array}{l}\text { Backet with } \\
\text { Trimming not } \\
\text { Center }\end{array}$ & $\begin{array}{l}\text { Bucket fastening bolts } \\
\text { loose }\end{array}$ & 48 & $\begin{array}{l}\text { - Check the condition of the machine before } \\
\text { carrying out the production process } \\
\text { - Tighten bolts and adjustments including backet } \\
\text { and trimming to center } \\
\text { - Changing the bolt if it is damaged or worn }\end{array}$ \\
\hline 3 & Leaking Lid & Material & Lip cup neven & $\begin{array}{l}\text { Quality of raw materials from } \\
\text { the supplier is not good }\end{array}$ & 48 & $\begin{array}{l}\text { - Check the material condition before carrying out } \\
\text { the production process } \\
\text { - Separation of the cup which is not standard } \\
\text { before it is put into the dispencer }\end{array}$ \\
\hline 4 & Leaking Lid & Machine & $\begin{array}{c}\text { Heater is not hot } \\
\text { nough }\end{array}$ & $\begin{array}{l}\text { Electricity often goes out } \\
\text { less electricity }\end{array}$ & 32 & $\begin{array}{l}\text { - Check the condition of the sealing unit before } \\
\text { carrying out the production process } \\
\text { - Check the temperature of the temperature on the } \\
\text { indicator before the production process runs } \\
\text { - Conduct intensive inspections of operators by } \\
\text { supervision }\end{array}$ \\
\hline
\end{tabular}




\begin{tabular}{|c|c|c|c|c|c|l|}
\hline 5 & $\begin{array}{c}\text { Less } \\
\text { Volume }\end{array}$ & Machine & $\begin{array}{c}\text { Pump supply is } \\
\text { less supportive }\end{array}$ & $\begin{array}{c}\text { Water filling is not } \\
\text { perfect }\end{array}$ & 30 & $\begin{array}{l}\text { Check the condition of the pump engine before } \\
\text { carrying out the production process } \\
\text { Need to increase pump capacity in accordance } \\
\text { with the needs of the production process }\end{array}$ \\
\hline
\end{tabular}




\section{References}

[1] Ahyari, Agus., Manajemen Pengendalian Produksi, Edisi 3, Penerbit BPFE, Yogyakarta, (1985).

[2] Ariani, Wahyu Dorotea., Manajemen Kualitas. Jakarta : Ghalia Indah, 2004. Bushido., Failure Mode and Effect Analysis (FMEA). Diakses tanggal 24 Maret

2011. Dari URL: http://bushido02.wordpress.com/2010/12/26/failure-

mode-and-effect-analysisfmea/.2010.

[3] Handoko, T.Hani., Manajemen Produksi dan Operasi. Edisi Pertama. Yogyakarta: BPFE-UGM. 2000.

[4] Indriyo Gitosudarmo., Sistem Perencanaan Dan Pengendalian Mutu, BPFE, Yogyakarta, (1992).

[5] Ranchman Prawiraamidjaja., Beberapa Pokok-Pokok Pelaksanaan Quality Control Dan Storage Control Pada Suatu Perusahaan, Tarsito, Bandung, (1998).

[6] Render, Barry dan Jay Heizer.,Prinsip-prinsip Manajemen Opersasi. Edisi ketujuh. Jakarta : Salem ba Empat, 2004.

[7] Sofyan Assauri., Manajemen Produksi, Edisi Ketiga, Penerbit Fakultas Ekonomi UI, Jakarta, (1999).

[8] Sukanto Reksohadiprodjo dan Indriyo G., Manajemen Produksi, Universitas Gajah Mada, Yogyakarta, (2000). 